Bangladesh J. Bot. 44(2): 299-307, 2015 (June)

\title{
EFFECTS OF AMINOETHOXYVINYLGLYCINE TREATMENTS ON PRE-HARVEST FRUIT DROP AND FRUIT QUALITY OF BRAEBURN APPLES
}

\author{
Burhan Ozturk*, Kenan Yildiz ${ }^{1}$, Yakup Ozkan ${ }^{2}$ and Kemal Kilic ${ }^{1}$ \\ Department of Horticulture, Faculty of Agriculture, University of Ordu, \\ 52200, Ordu-Turkey
}

Key words: Aminoethoxyvinylglycine, Pre-harvest fruit drop, Fruit quality, Braeburn apples

\begin{abstract}
This study was conducted to determine the effects of increasing aminoethoxyvinylglycine (AVG) concentrations on pre-harvest drop and fruit quality parameters of 'Braeburn' apples. Results revealed that AVG treatments increased the fruit removal force and significantly decreased pre-harvest drops compared to control treatment. AVG was found to be more effective in controlling pre-harvest drops than naphthaleneacetic acid (NAA). There were significant differences among AVG doses with regard to preharvest drop rates. The lowest ratio of pre-harvest drop was observed in $400 \mathrm{mg} / \mathrm{l} \mathrm{AVG}$ treatment. All AVG doses decreased ethylene biosynthesis. Inhibition of ethylene biosynthesis was higher in 300 and $400 \mathrm{mg} / 1$ AVG treatments than the other AVG treatment. AVG retarded fruit ripening of 'Braeburn' apples. Measurements, performed at different dates of ripening process, revealed higher flesh firmness values for AVG-treated fruits than the control. Starch degradation was delayed by AVG treatments. Effects of AVG on fruit peel color varied with years. While significant effects of AVG treatments on peel color were not observed in the first year, especially higher AVG doses significantly increased $L^{*}$ values and hue angles in the second year. AVG treatments also significantly increased fruit mass in both years. Significant changes in fruit geometric diameters were not observed with AVG treatments, except for $300 \mathrm{mg} / \mathrm{l} \mathrm{AVG}$ treatment of second year.
\end{abstract}

\section{Introduction}

Apple is a climacteric fruit and distinctive increases are observed in ethylene synthesis toward the fruit ripening (Blanpied 1972). Increased ethylene production stimulates fruit maturity and synthesis of polygalacturonase-like enzymes degrading cell walls in abscission zone (Brown 1997, Bonghi et al. 2000). Thus, increased ethylene production decreases fruit removal force and increases fruit drops before to reach sufficient ripening levels. Such a case, also called as preharvest drop, result in significant yield losses because of insufficient fruit sizes and color formations.

Various growth regulators have been used to reduce drop rates. Naphthaleneacetic acid (NAA) is one of those growth regulators and it has been used to prevent pre-harvest drops for about half a century (Gardner et al. 1939). Although some researchers reported significant impacts of NAA in controlling pre-harvest drops (Marini et al. 1993, Curry 2006), some others indicated that this chemical has been either inefficient or inconsistent in controlling pre-harvest fruit drops depending on cultivars and climate factors (Byers 1997, Yildiz et al. 2012). Recently, aminoethoxyvinylglycine (AVG), a natural ethylene inhibitor, has been used as an alternative to NAA to prevent pre-harvest drops in apples. It was reported in several previous studies that AVG retarded fruit ripening by inhibiting ethylene synthesis and is more effective than NAA in controlling pre-harvest drops (Schupp and Greene 2004, Dal Cin et al. 2008). Although AVG was

*Author for correspondence: < burhanozturk55@gmail.com>. ${ }^{1}$ Department of Horticulture, Faculty of Agriculture, University of Gaziosmanpaşa, 60240, Tokat-Turkey. ${ }^{2}$ Department of Horticulture, Faculty of Agriculture, University of Süleyman Demirel, 32200, Isparta-Turkey. 
found to be an effective compound to control pre-harvest drops in apples, response of different cultivars may significantly vary. Greene (2006) indicated that low AVG doses should be used in cultivars with low ethylene production such as "Gala".

In present study, an attempt was made to ascertain optimum AVG dose for controlling the pre-harvest drops in 'Braeburn' apples.

\section{Materials and Methods}

This study was conducted at Horticultural Research Centre of Gaziosmanpaşa University $\left(40^{\circ} 20^{\prime} 02.19^{\prime \prime} \mathrm{N}\right.$ latitude and $36^{\circ} 28^{\prime} 30.11 " \mathrm{E}$ longitude, and $623 \mathrm{~m}$ above sea level) of Tokat Province, located in middle Black Sea Region of Turkey.

To determine the effects of AVG on pre-harvest drop and fruit quality, 5 year old 56 'Braeburn' trees (Malus domestica Borkh.) grafted on MM106 rootstock were selected and grouped into four blocks with 14 trees in each based on proximity in orchard and crop load. AVG was applied in five different concentrations $(100,200,300,400$ and $500 \mathrm{mg} / \mathrm{l}) 4$ weeks before the anticipated harvest time (on 18th of September in 2010 and on 24th of September in 2011).

NAA at $20 \mathrm{mg} / \mathrm{l}$ was sprayed 4 and 2 weeks before the anticipated harvest as a positive control. All spray solutions contained 'Sylgard-309' as surfactant $[0.05 \%$, v/v (Dow Corning, Canada)]. Treatments were applied with a low pressure hand sprayer. For each treatment, one pair of trees was used in each block. One tree in each pair was designated to be the sample tree, from which fruits were collected for ethylene and quality analysis at predetermined date. No fruit were harvested from second tree until normal harvest time and this served to follow the progression of fruit drop. Two trees in each block were not sprayed and served as control.

To determine pre-harvest fruit drop ratio, fruits fallen under tree were counted twice a week starting 30 days before the anticipated harvest date until the harvest time. Then, fruits remaining on the trees were harvested and drop ratio was calculated. Ten fruits were harvested randomly from each sample tree on 25 September, 2, 9 and 16 October (2010), and 1, 8, 15 and 22 October (2011) to determine fruit removal force, fruit flesh firmness, starch degradation and color, fruit mass and geometric diameter. While these fruits were collected, fruit removal force, the force required to remove fruit from shoot, was measured with a dynamometer (Tronic HF-10, Taiwan). Fruit mass (g) were measured with a digital balance $( \pm 0.01 \mathrm{~g})$ (Radvag, Poland). Fruit length (L), width (W) and thickness $(\mathrm{T})$ were measured with a digital caliper $( \pm 0.01 \mathrm{~mm})(\mathrm{CD}-6 \mathrm{CSX}$, Mitutoyo, Japan). Geometric diameter was determined by using the relationship (Geometric diameter $\left.=(L W T)^{1 / 3}\right)$ described by Mohsenin (1970). Peel color of the sun-exposed side of each fruit was analyzed with a colorimeter (CR-400, Japan). Measurements were obtained by using the CIE $L^{*}, \mathrm{a}^{*}$ and $\mathrm{b}^{*}$ color space, then $\mathrm{a}^{*}$ and $\mathrm{b}^{*}$ values were converted into hue angle and chroma (McGuire 1992). A five-fruit sub-sample was then selected for flesh firmness. Flesh firmness was determined on three sides of equatorial line of each fruit with a press-mounted Effegi penetrometer (FT 327, USA) with $11.1 \mathrm{~mm}$ tip. The other sub-samples of five fruit were used for starch degradation. Starch-iodine tests of sliced fruits were carried out by using the Cornell Generic Starch-Iodine Index Chart, where $1=100 \%$ starch and $8=0 \%$ starch (Blanpied and Silsby 1992).

To evaluate the internal ethylene concentration, ten fruits were randomly harvested from one tree in each block for each treatment on 1, 8,15 and 22 October, 2011. Each apple was held under water. A spinal needle was pushed through the pericarp into the core. A stainless steel wire in the bore prevented the needle from plugging with tissue during this process, and the wire was removed. Then a $1 \mathrm{ml}$ air sample from core cavity of each fruit was injected into a gas chromatographer equipped with an active alumina column and Flame Ionization Detector (Clarus 
500, USA), using the method of Bramlage et al. (1980). The resultant peaks were compared to that of $100 \mu \mathrm{l} / \mathrm{l}$ ethylene standards and the internal ethylene concentration.

A randomized complete block design was used. All statistical analyses were performed with SAS Version 9.1 (SAS, USA). Data normality was confirmed by the Kolmogorov-Smirnov test and the homogeneity of variances by the Levene's test. Data were analyzed by analysis of variance. Means were compared by DMRT at a significance level of 0.05 .

\section{Results and Discussion}

In both experimental years, higher AVG doses significantly reduced the drop rates. All AVG treatments, as to be more distinctive in higher doses, decreased fruit drop. The lowest drop was observed in $400 \mathrm{mg} / \mathrm{l}$ AVG treatment in both years. NAA treatment significantly decreased drop rates during the first year except for the first measurement date (Table 1).

Table 1. Effects of NAA and AVG treatments on cumulative drop ratio of 'Braeburn' apple.

\begin{tabular}{|c|c|c|c|c|}
\hline \multirow{3}{*}{ Treatments } & \multicolumn{4}{|c|}{ Cumulative drop ratio ( $\%$ of total) } \\
\hline & \multicolumn{4}{|c|}{2010} \\
\hline & 25 Sept. & 2 Oct. & 9 Oct. & 16 Oct. \\
\hline Control & $16.05 \mathrm{a}$ & $38.97 \mathrm{a}$ & $46.91 \mathrm{a}$ & $55.80 \mathrm{a}$ \\
\hline $100 \mathrm{mg} / \mathrm{l}, \mathrm{AVG}^{*}$ & $15.70 \mathrm{a}$ & $26.82 \mathrm{~b}$ & $35.14 \mathrm{~b}$ & $38.47 \mathrm{~b}$ \\
\hline $200 "$ & $16.21 \mathrm{a}$ & $24.66 \mathrm{~b}$ & $27.86 \mathrm{c}$ & $31.99 \mathrm{c}$ \\
\hline $300 "$ & $9.00 \mathrm{~b}$ & $17.31 \mathrm{c}$ & $23.32 \mathrm{c}$ & $25.79 \mathrm{~d}$ \\
\hline $400 "$ & $6.60 \mathrm{~b}$ & $11.65 \mathrm{c}$ & $13.71 \mathrm{~d}$ & $15.79 \mathrm{e}$ \\
\hline $500 "$ & $7.01 \mathrm{~b}$ & $16.96 \mathrm{c}$ & $24.21 \mathrm{c}$ & $25.99 \mathrm{~d}$ \\
\hline \multirow[t]{3}{*}{$20 \mathrm{mg} / \mathrm{l}, \mathrm{NAA}^{* *}$} & $20.70 \mathrm{a}$ & $29.49 \mathrm{~b}$ & $36.83 \mathrm{~b}$ & $41.18 \mathrm{~b}$ \\
\hline & \multicolumn{4}{|c|}{2011} \\
\hline & 1 Oct. & 8 Oct. & 15 Oct. & 22 Oct. \\
\hline Control & $7.52 \mathrm{a}$ & $18.82 \mathrm{a}$ & $27.29 \mathrm{a}$ & $38.36 \mathrm{a}$ \\
\hline $100 \mathrm{mg} / \mathrm{l}, \mathrm{AVG}^{*}$ & $7.14 \mathrm{a}$ & $14.29 \mathrm{~b}$ & $23.29 \mathrm{~b}$ & $30.12 b$ \\
\hline $200 "$ & $7.85 \mathrm{a}$ & $12.03 \mathrm{~b}$ & $15.70 \mathrm{c}$ & $22.51 \mathrm{c}$ \\
\hline $300 "$ & $1.30 \mathrm{~b}$ & $8.16 \mathrm{c}$ & $12.03 \mathrm{~d}$ & $21.46 \mathrm{c}$ \\
\hline $400 "$ & $1.85 \mathrm{~b}$ & $4.63 \mathrm{~d}$ & 8.79 e & $11.12 \mathrm{~d}$ \\
\hline $500 "$ & $2.38 \mathrm{~b}$ & $4.99 \mathrm{~d}$ & $11.99 \mathrm{~d}$ & $20.33 c$ \\
\hline $20 \mathrm{mg} / \mathrm{l}, \mathrm{NAA}^{* *}$ & $7.18 \mathrm{a}$ & $18.38 \mathrm{a}$ & $29.91 \mathrm{a}$ & $36.46 \mathrm{a}$ \\
\hline
\end{tabular}

*AVG was applied on 18 September, 2010 and 24 September, 2011; **NAA was applied on 18 September and 2 October, 2010 and 24 September and 8 October, 2011. Means in columns with the same letter do not differ, according to DMRT, $\mathrm{p}<0.05$.

Drop rates of the year 2010 were generally higher than the year 2011. The differences between the years may be due to climate, especially temperature differences. In fact, average temperature during fruit growth periods in 2010 [September $\left(23.3^{\circ} \mathrm{C}\right)$ and October $\left(14.1^{\circ} \mathrm{C}\right)$ ] was higher than that in 2011 [September $\left(18.3^{\circ} \mathrm{C}\right)$ and October $\left.\left(12.9^{\circ} \mathrm{C}\right)\right]$. Beside various environmental factors, temperatures are well documented to have effects on pre-harvest drops in apples (Ward 2004).

The results of this study showed once again that AVG treatments significantly decreased preharvest drop rates of apples and that AVG was more effective in controlling fruit drop than NAA. 
These results are consistent with the results of previous studies carried out with different apple varieties (Williams 1980, Byers 1997, Stover et al. 2003, Kang et al. 2007). NAA decreased drop rates in the first year but did not have significant effects on drop rates of the second year. Beside the studies indicating significant effects of NAA on pre-harvest drop in apples (Yuan and Carbaugh 2007, Dal Cin et al. 2008), there are some other studies reporting similar results with the present study indicating that this chemical does not always give the expected outcomes depending on cultivars and climate factors (Greene and Schupp 2004, Curry 2006).

Fruit ethylene biosynthesis was measured during only the second year. All AVG treatments significantly decreased internal ethylene concentrations. Ethylene concentrations in NAA treatments were lower than that in control treatment in all measurement dates except for 15 October (Table 2).

Table 2. Effects of NAA and AVG treatments on internal ethylene concentrations of 'Braeburn' apple.

\begin{tabular}{llccl}
\hline Treatments & \multicolumn{4}{c}{ Internal ethylene concentration $(\mathrm{mg} / \mathrm{l})$} \\
\cline { 2 - 5 } & 1 Oct. & 8 Oct. & 15 Oct. & 22 Oct. \\
\hline Control & $27.24 \mathrm{a}$ & $44.07 \mathrm{a}$ & $50.55 \mathrm{a}$ & $81.91 \mathrm{a}$ \\
$100 \mathrm{mg} / \mathrm{l}_{\mathrm{y}} \mathrm{AVG}^{*}$ & $26.16 \mathrm{ab}$ & $39.09 \mathrm{~b}$ & $49.46 \mathrm{a}$ & $60.39 \mathrm{~b}$ \\
$200 "$ & $20.39 \mathrm{~d}$ & $31.91 \mathrm{~d}$ & $39.69 \mathrm{~b}$ & $55.65 \mathrm{c}$ \\
$300 "$ & $20.41 \mathrm{~d}$ & $34.49 \mathrm{c}$ & $37.35 \mathrm{~b}$ & $37.98 \mathrm{e}$ \\
$400 "$ & $21.89 \mathrm{~cd}$ & $22.25 \mathrm{f}$ & $34.31 \mathrm{c}$ & $37.35 \mathrm{e}$ \\
$500 "$ & $24.07 \mathrm{bc}$ & $29.36 \mathrm{e}$ & $34.08 \mathrm{c}$ & $50.12 \mathrm{~d}$ \\
$20 \mathrm{mg} / 1, \mathrm{NAA}^{* *}$ & $24.10 \mathrm{bc}$ & $35.38 \mathrm{c}$ & $50.48 \mathrm{a}$ & $60.93 \mathrm{~b}$ \\
\hline
\end{tabular}

${ }^{*}$ AVG was applied on 24 September, 2011; ${ }^{* *}$ NAA was applied on 24 September and 8 October, 2011. $\mathrm{n}=40$ (ten fruits $\times$ four replications) for internal ethylene concentration. Means in columns with the same letter do not differ, according to DMRT, $\mathrm{p}<0.05$.

Increasing ethylene synthesis toward to maturity stimulates fruit softening and the formation of an abscission zone in the stem. Ethylene stimulates the production of enzymes (cellulose and polyglacturonase) that break down the cell walls and the glue that holds cell walls together in the abscission zone of the stem, weakening fruit removal force. It was assumed that AVG controls pre-harvest drops in apples by inhibiting internal ethylene synthesis (Greene and Schupp 2004, Silverman et al. 2004, Greene 2006). In the present study, AVG clearly inhibited ethylene production and increased fruit removal force. Increased removal forces with AVG treatments were also reported by Bangerth (1978) in 'Golden Delicious' apples and by Yildiz et al. (2012) in 'Red Chief' apples. Ethylene biosynthesis-inhibiting effect of AVG and consequent retardations in fruit ripening were reported in different apple varieties (Autio and Bramlage 1982, Chu 1998). Similar findings were observed in 'Braeburn' apples of the present study.

Firmness of fruits harvested on 2 October and subsequent dates was higher in AVG treatments than control treatment of first year. 300, 400 and $500 \mathrm{mg} / \mathrm{l} \mathrm{AVG}$ treatments had higher fruit firmness values than 100 and $200 \mathrm{mg} / \mathrm{l} \mathrm{AVG}$ treatments. In the second year, on the final harvest, the highest fruit firmness was observed in $300 \mathrm{mg} / \mathrm{l} \mathrm{AVG}$ treatment, followed by 500 and $400 \mathrm{mg} / \mathrm{l} \mathrm{AVG}$ treatments (Table 3).

Fruit flesh firmness is an important quality and ripening criteria for apple fruit. AVG provided significant contributions in preservation of flesh firmness of 'Braeburn' apples. Flesh firmness of AVG-treated fruits was higher than the control fruits in all measurement dates. Similarly, AVG retarded starch degradation of 'Braeburn' apples. These findings are consistent with the results 
obtained for 'McIntosh', 'Northern Spy', 'Emperie', 'Mutsu' and 'Idared' (Chu 1998), 'Macspur McIntosh' and 'Marshall McIntosh' (Greene and Schupp 2004), 'Fuji' and 'Gala' (Petri et al. 2006), ‘Golden Supreme' and 'Golden Delicious' apples (Yuan and Carbaugh 2007).

Table 3. Effects of NAA and AVG treatments on fruit firmness of 'Braeburn' apple.

\begin{tabular}{|c|c|c|c|c|}
\hline \multirow{3}{*}{ Treatments } & \multicolumn{4}{|c|}{ Fruit firmness $(\mathrm{N})$} \\
\hline & \multicolumn{4}{|c|}{2010} \\
\hline & 25 Sept. & 2 Oct. & 9 Oct. & 16 Oct. \\
\hline Control & $90.91 \mathrm{a}$ & $85.14 \mathrm{~b}$ & $81.70 \mathrm{c}$ & $77.92 \mathrm{c}$ \\
\hline $100 \mathrm{mg} / 1, \mathrm{AVG}^{*}$ & $90.67 \mathrm{a}$ & $88.42 \mathrm{a}$ & $84.00 \mathrm{~b}$ & $80.68 \mathrm{bc}$ \\
\hline $200 "$ & $91.13 \mathrm{a}$ & $88.88 \mathrm{a}$ & $85.92 \mathrm{~b}$ & $82.87 \mathrm{~b}$ \\
\hline $300 "$ & $91.41 \mathrm{a}$ & $88.50 \mathrm{a}$ & $87.24 \mathrm{a}$ & $86.90 \mathrm{a}$ \\
\hline $400 "$ & $91.60 \mathrm{a}$ & $87.62 \mathrm{a}$ & $86.22 \mathrm{a}$ & $84.68 \mathrm{a}$ \\
\hline $500 "$ & $91.06 \mathrm{a}$ & $88.13 \mathrm{a}$ & $86.95 \mathrm{a}$ & $85.83 \mathrm{a}$ \\
\hline \multirow[t]{3}{*}{$20 \mathrm{mg} / \mathrm{l}, \mathrm{NAA}^{* *}$} & $90.27 \mathrm{a}$ & $87.76 \mathrm{a}$ & $82.86 \mathrm{c}$ & $80.86 \mathrm{bc}$ \\
\hline & \multicolumn{4}{|c|}{2011} \\
\hline & 1 Oct. & 8 Oct. & 15 Oct. & 22 Oct. \\
\hline Control & $102.5 \mathrm{bc}$ & $87.2 \mathrm{~b}$ & $85.9 \mathrm{bc}$ & $75.6 \mathrm{~d}$ \\
\hline $100 \mathrm{mg} / \mathrm{l}, \mathrm{AVG}^{*}$ & $104.7 \mathrm{~b}$ & $90.2 \mathrm{ab}$ & $83.3 \mathrm{c}$ & $81.8 \mathrm{c}$ \\
\hline $200 "$ & $105.5 \mathrm{~b}$ & $92.7 \mathrm{a}$ & $90.0 \mathrm{a}$ & $83.4 \mathrm{bc}$ \\
\hline $300 "$ & $110.9 \mathrm{a}$ & $93.2 \mathrm{a}$ & $90.6 \mathrm{a}$ & $89.7 \mathrm{a}$ \\
\hline $400 "$ & $106.3 \mathrm{~b}$ & $89.5 \mathrm{ab}$ & $88.2 \mathrm{ab}$ & $85.9 \mathrm{~b}$ \\
\hline $500 "$ & $100.7 \mathrm{c}$ & $89.5 \mathrm{ab}$ & $89.4 \mathrm{ab}$ & $87.1 \mathrm{ab}$ \\
\hline $20 \mathrm{mg} / \mathrm{l}, \mathrm{NAA}^{* *}$ & $105.1 \mathrm{~b}$ & $86.6 \mathrm{~b}$ & $83.6 \mathrm{c}$ & $83.4 \mathrm{bc}$ \\
\hline
\end{tabular}

${ }^{*}$ AVG was applied on 18 September, 2010 and 24 September, 2011; ${ }^{* *}$ NAA was applied on 18 September and 2 October, 2010 and 24 September and 8 October, 2011. $n=60$ (five fruits $\times$ four replications $\times$ three measurements for each fruit) for flesh firmness. Means in columns with the same letter do not differ, according to DMRT, $\mathrm{p}<0.05$.

In the first year, AVG treatments did not have significant effects on fruit removal force in early stages. On the last harvest, the highest fruit removal force was observed in 400 and $500 \mathrm{mg} / \mathrm{l}$ AVG treatments. In the second year, 400 and $500 \mathrm{mg} / \mathrm{l} \mathrm{AVG}$ treatments significantly increased the removal forces (Table 4).

On 9 October, 300, 400 and $500 \mathrm{mg} / 1 \mathrm{AVG}$ treatments had lower starch index values than control, 100 and $200 \mathrm{mg} / \mathrm{l} \mathrm{AVG}$ and NAA treatments. On the last harvest, all AVG doses had lower starch index than the control and NAA treatments. In the second year, all AVG treatments delayed starch degradation (Table 5).

All AVG treatments, except for $100 \mathrm{mg} / \mathrm{l}$, had higher $L^{*}$ values than the control treatment in 2011. 400 and $500 \mathrm{mg} / \mathrm{l}$ AVG treatments significantly increased the hue angles of the second year. Such an increase in hue angle was more distinctive in $500 \mathrm{mg} / \mathrm{l} \mathrm{AVG}$ treatment. NAA did not cause any significant changes in color parameters of both years compared to the control treatment (Table 6). 
Table 4. Effects of NAA and AVG treatments on fruit removal force of 'Braeburn' apple.

\begin{tabular}{|c|c|c|c|c|}
\hline \multirow{3}{*}{ Treatments } & \multicolumn{4}{|c|}{ Fruit removal force $(\mathrm{N})$} \\
\hline & \multicolumn{4}{|c|}{2010} \\
\hline & 25 Sept. & 2 Oct. & 9 Oct. & 16 Oct. \\
\hline Control & $21.38 \mathrm{a}$ & $19.86 \mathrm{a}$ & $12.49 \mathrm{c}$ & $11.85 \mathrm{c}$ \\
\hline $100 \mathrm{mg} / \mathrm{l}, \mathrm{AVG}^{*}$ & $21.00 \mathrm{a}$ & $17.31 \mathrm{~b}$ & $14.03 \mathrm{c}$ & $13.21 \mathrm{bc}$ \\
\hline $200 "$ & $21.70 \mathrm{a}$ & $18.90 \mathrm{ab}$ & $16.35 \mathrm{~b}$ & $14.11 \mathrm{~b}$ \\
\hline $300 "$ & $21.06 \mathrm{a}$ & $19.82 \mathrm{a}$ & $18.82 \mathrm{a}$ & $15.13 \mathrm{~b}$ \\
\hline $400 "$ & $21.14 \mathrm{a}$ & $19.09 \mathrm{ab}$ & $18.80 \mathrm{a}$ & $17.47 \mathrm{a}$ \\
\hline $500 "$ & $21.02 \mathrm{a}$ & $19.91 \mathrm{a}$ & $18.55 \mathrm{a}$ & $17.80 \mathrm{a}$ \\
\hline \multirow[t]{3}{*}{$20 \mathrm{mg} / 1, \mathrm{NAA}^{* *}$} & $21.45 \mathrm{a}$ & $17.98 \mathrm{ab}$ & $13.52 \mathrm{c}$ & $12.28 \mathrm{c}$ \\
\hline & \multicolumn{4}{|c|}{2011} \\
\hline & 1 Oct. & 8 Oct. & 15 Oct. & 22 Oct. \\
\hline Control & $19.23 \mathrm{~b}$ & $16.12 \mathrm{~b}$ & $14.43 \mathrm{c}$ & $12.62 \mathrm{c}$ \\
\hline $100 \mathrm{mg} / 1, \mathrm{AVG}^{*}$ & $19.49 \mathrm{~b}$ & $16.70 \mathrm{~b}$ & $15.35 \mathrm{c}$ & $13.71 \mathrm{c}$ \\
\hline $200 "$ & $18.77 \mathrm{~b}$ & $16.47 \mathrm{~b}$ & $14.57 \mathrm{c}$ & $14.46 \mathrm{bc}$ \\
\hline $300 "$ & $20.82 \mathrm{~b}$ & $17.74 \mathrm{~b}$ & $15.65 \mathrm{c}$ & $16.62 \mathrm{ab}$ \\
\hline $400 "$ & $24.15 \mathrm{a}$ & $21.13 \mathrm{a}$ & $18.37 \mathrm{~b}$ & $18.33 \mathrm{a}$ \\
\hline $500 "$ & $25.92 \mathrm{a}$ & $22.54 \mathrm{a}$ & $20.09 \mathrm{a}$ & $19.78 \mathrm{a}$ \\
\hline $20 \mathrm{mg} / \mathrm{l}, \mathrm{NAA}^{* *}$ & $18.15 \mathrm{~b}$ & $16.06 \mathrm{~b}$ & $15.20 \mathrm{c}$ & $13.10 \mathrm{c}$ \\
\hline
\end{tabular}

*AVG was applied on 18 September, 2010 and 24 September, 2011; ${ }^{* *}$ NAA was applied on 18 September and 2 October, 2010 and 24 September and 8 October, 2011. $n=40$ (ten fruits $\times$ four replications) for fruit removal force. Means in columns with the same letter do not differ, according to DMRT, $\mathrm{p}<0.05$.

Table 5. Effects of NAA and AVG treatments on starch degradation of 'Braeburn' apple.

\begin{tabular}{|c|c|c|c|c|}
\hline \multirow{3}{*}{ Treatments } & \multicolumn{4}{|c|}{ Starch degradation $(0-8)^{* * *}$} \\
\hline & \multicolumn{4}{|c|}{2010} \\
\hline & 25 Sept. & 2 Oct. & 9 Oct. & 16 Oct. \\
\hline Control & $3 \mathrm{a}$ & $4 \mathrm{~b}$ & $5 \mathrm{~b}$ & $7 \mathrm{a}$ \\
\hline $100 \mathrm{mg} / 1, \mathrm{AVG}^{*}$ & $3 a$ & $4 \mathrm{~b}$ & $5 \mathrm{~b}$ & $6 \mathrm{~b}$ \\
\hline $200 "$ & $3 a$ & $4 \mathrm{~b}$ & $5 \mathrm{~b}$ & $6 \mathrm{~b}$ \\
\hline $300 "$ & $3 \mathrm{a}$ & $4 \mathrm{~b}$ & $4 \mathrm{c}$ & $6 \mathrm{~b}$ \\
\hline $400 "$ & $3 a$ & $3 \mathrm{c}$ & $4 \mathrm{c}$ & $4 \mathrm{~d}$ \\
\hline $500 "$ & $2 \mathrm{~b}$ & $4 \mathrm{~b}$ & $4 \mathrm{c}$ & $5 \mathrm{c}$ \\
\hline \multirow[t]{3}{*}{$20 \mathrm{mg} / 1, \mathrm{NAA}^{* *}$} & $3 \mathrm{a}$ & $5 \mathrm{a}$ & $6 \mathrm{a}$ & $7 \mathrm{a}$ \\
\hline & \multicolumn{4}{|c|}{2011} \\
\hline & 1 Oct. & 8 Oct. & 15 Oct. & 22 Oct. \\
\hline Control & $3 \mathrm{~b}$ & $6 \mathrm{a}$ & $6 \mathrm{a}$ & $7 \mathrm{a}$ \\
\hline $100 \mathrm{mg} / 1, \mathrm{AVG}^{*}$ & $3 \mathrm{~b}$ & $4 \mathrm{c}$ & $5 \mathrm{~b}$ & $7 \mathrm{a}$ \\
\hline $200 "$ & $3 \mathrm{~b}$ & $4 \mathrm{c}$ & $5 \mathrm{~b}$ & $6 \mathrm{~b}$ \\
\hline $300 "$ & $3 \mathrm{~b}$ & $4 \mathrm{c}$ & $4 \mathrm{c}$ & $6 \mathrm{~b}$ \\
\hline $400 "$ & $2 \mathrm{c}$ & $5 \mathrm{~b}$ & $4 \mathrm{c}$ & $5 \mathrm{c}$ \\
\hline $500 "$ & $4 \mathrm{a}$ & $4 \mathrm{c}$ & $4 \mathrm{c}$ & $5 \mathrm{c}$ \\
\hline $20 \mathrm{mg} / \mathrm{l}, \mathrm{NAA}^{* *}$ & $3 \mathrm{~b}$ & $4 \mathrm{c}$ & $5 \mathrm{~b}$ & $7 \mathrm{a}$ \\
\hline
\end{tabular}

*AVG was applied on 18 September, 2010 and 24 September, 2011; ${ }^{* *}$ NAA was applied on 18 September and 2 October, 2010 and 24 September and 8 October, 2011. ${ }^{* * *} 1=100 \%$ starch and $8=0 \%$ starch. $\mathrm{n}=20$ (five fruits $\times$ four replications) for starch. Means in columns with the same letter do not differ, according to DMRT, $\mathrm{p}<0.05$. 
A disadvantage of inhibiting ethylene synthesis by AVG was reported as a delay in red peel color development of apples (Greene and Schupp 2004, Whale et al. 2008). Wargo et al. (2004) reported decreasing red color intensities (higher hue angle) with AVG treatments compared to the control treatment. Yildiz et al. (2012), on the other hand, indicated that AVG did not have significant effects on peel color and only the high doses $(600 \mathrm{mg} / \mathrm{l})$ increased $L^{*}$ values and hue angles. Although significant effects of AVG on color parameters of the year 2010 were not observed in present study, especially high AVG doses significantly increased $L^{*}$ and hue angles of the year 2011. Greene (2006) reported that AVG did not directly increased fruit sizes and increasing fruit sizes were just because of delayed maturation and consequent late harvests. Despite the non-delayed harvests of the present study, entire AVG treatments increased fruit sizes and only $300 \mathrm{mg} / \mathrm{l} \mathrm{AVG}$ treatment increased geometric diameter.

Table 6. Effects of NAA and AVG treatments on color parameters ( $L^{*}$, chroma and hue angle) of 'Braeburn' apple.

\begin{tabular}{|c|c|c|c|c|c|c|}
\hline \multirow{3}{*}{ Treatments } & \multicolumn{6}{|c|}{ Color characteristics } \\
\hline & \multicolumn{2}{|c|}{$L^{*}$} & \multicolumn{2}{|c|}{ Chroma } & \multicolumn{2}{|c|}{ Hue angle } \\
\hline & 2010 & 2011 & 2010 & 2011 & 2010 & 2011 \\
\hline Control & $57.62 \mathrm{a}$ & $52.71 \mathrm{c}$ & $42.54 \mathrm{ab}$ & $39.07 \mathrm{~b}$ & $69.74 \mathrm{ab}$ & $59.83 \mathrm{c}$ \\
\hline $100 \mathrm{mg} / \mathrm{l}, \mathrm{AVG}^{*}$ & $58.34 \mathrm{a}$ & $53.22 \mathrm{bc}$ & $43.12 \mathrm{a}$ & $39.58 \mathrm{ab}$ & $71.04 \mathrm{a}$ & $61.50 \mathrm{bc}$ \\
\hline $200 "$ & $56.88 \mathrm{a}$ & $54.06 \mathrm{ab}$ & $39.81 \mathrm{c}$ & $40.29 \mathrm{ab}$ & $69.12 \mathrm{ab}$ & $63.65 \mathrm{bc}$ \\
\hline $300 "$ & $57.64 \mathrm{a}$ & $55.12 \mathrm{ab}$ & $41.40 \mathrm{~b}$ & $40.91 \mathrm{ab}$ & $71.74 \mathrm{a}$ & $63.83 \mathrm{bc}$ \\
\hline $400 "$ & $58.98 \mathrm{a}$ & $57.00 \mathrm{a}$ & $42.58 \mathrm{ab}$ & $40.65 \mathrm{ab}$ & $72.42 \mathrm{a}$ & $66.32 \mathrm{~b}$ \\
\hline $500 "$ & $57.21 \mathrm{a}$ & $58.81 \mathrm{a}$ & $41.63 \mathrm{ab}$ & $41.74 \mathrm{a}$ & $67.24 \mathrm{~b}$ & $80.55 \mathrm{a}$ \\
\hline $20 \mathrm{mg} / 1, \mathrm{NAA}^{* *}$ & $57.90 \mathrm{a}$ & $51.51 \mathrm{c}$ & $41.55 \mathrm{ab}$ & $39.14 \mathrm{~b}$ & $70.54 \mathrm{ab}$ & $59.51 \mathrm{c}$ \\
\hline
\end{tabular}

${ }^{*}$ AVG was applied on 18 September, 2010 and 24 September, 2011; ${ }^{* *}$ NAA was applied on 18 September and 2 October, 2010 and 24 September and 8 October, 2011. n=80 (ten fruits $\times$ four replications $\times$ two measurements for each fruit) for $L^{*}$, chroma and hue angle. Means in columns with the same letter do not differ, according to DMRT, $\mathrm{p}<0.05$.

All AVG treatments significantly increased fruit mass of both years. The highest fruit mass was observed in $300 \mathrm{mg} / \mathrm{l} \mathrm{AVG}$ treatment. In 2011, while $300 \mathrm{mg} / \mathrm{l}$ AVG-treated fruits had higher geometric diameter than control fruits, the geometric diameters of fruits treated with the other AVG doses and NAA were similar to control fruits (Table 7).

Table 7. Effects of NAA and AVG treatments on fruit mass and geometric diameter of 'Braeburn' apple.

\begin{tabular}{lcccc}
\hline Treatments & \multicolumn{2}{c}{ Fruit mass $(\mathrm{g})$} & \multicolumn{2}{c}{ Geometric diameter $(\mathrm{mm})$} \\
\cline { 2 - 5 } & 2010 & 2011 & 2010 & 2011 \\
\hline Control & $175.5 \mathrm{~d}$ & $176.3 \mathrm{e}$ & $67.8 \mathrm{a}$ & $68.1 \mathrm{~b}$ \\
$100 \mathrm{mg} / 1, \mathrm{AVG}^{*}$ & $182.0 \mathrm{c}$ & $181.3 \mathrm{~d}$ & $67.7 \mathrm{a}$ & $68.4 \mathrm{ab}$ \\
$200 \mathrm{"}$ & $185.8 \mathrm{~b}$ & $187.3 \mathrm{~b}$ & $69.2 \mathrm{a}$ & $68.6 \mathrm{ab}$ \\
$300 \mathrm{~F}$ & $193.5 \mathrm{a}$ & $195.6 \mathrm{a}$ & $68.8 \mathrm{a}$ & $70.5 \mathrm{a}$ \\
400 & $182.5 \mathrm{c}$ & $184.6 \mathrm{c}$ & $67.5 \mathrm{a}$ & $69.5 \mathrm{ab}$ \\
$500 "$ & $189.6 \mathrm{~b}$ & $183.5 \mathrm{c}$ & $68.0 \mathrm{a}$ & $69.9 \mathrm{ab}$ \\
$20 \mathrm{mg} / 1, \mathrm{NAA}^{* *}$ & $178.7 \mathrm{~d}$ & $176.6 \mathrm{e}$ & $68.4 \mathrm{a}$ & $67.9 \mathrm{~b}$ \\
\hline
\end{tabular}

*AVG was applied on 18 September, 2010 and 24 September, 2011; ${ }^{* *}$ NAA was applied on 18 September and 2 October, 2010 and 24 September and 8 October, 2011. $n=40$ (ten fruits $\times$ four replications) for fruit mass and geometric diameter. Means in columns with the same letter do not differ, according to DMRT, $\mathrm{p}<$ 0.05 . 
Finally, current findings suggest that the effects of AVG sprays on 'Breaburn' apples could be of great economic benefit to growers by reducing the losses due to pre-harvest fruit drops, loss of fruit firmness, starch and storage quality before the harvest.

\section{Acknowledgement}

Authors are thankful to the authority of Scientific and Technological Research Council of Turkey (TUBITAK) for financial support (Project number: 111 O 050).

\section{References}

Autio WR and Bramlage W 1982. Effect of AVG on maturation, ripening and storage of apples. J. Amer. Soc. Hortic. Sci. 107: 1074-1077.

Bangerth F 1978. The effect of a substituted amino acid on ethylene biosynthesis, respiration, ripening and preharvest drop of apple fruits. J. Amer. Soc. Hortic. Sci. 103: 401-404.

Blanpied GD 1972. A study of ethylene in apple, red raspberry, and cherry. Plant Physiol. 49: 627-630.

Blanpied GD and Silsby KJ 1992. Prediction of harvest date windows for apples. Cornell Coop. Exten. Bull. 2212: $1-12$.

Bonghi, C., P. Tonutti and A. Ramina. 2000. Biochemical and molecular aspect of fruitlet abscission. Plant Growth Regul. 31: 35-42.

Bramlage WJ, Greene DW, Autio WR and Mclaughlin JM 1980. Effect of aminoethoxyvinylglycine on internal ethylene concentration and storage of apples. J. Amer. Soc. Hortic. Sci. 105: 847-851.

Brown KM 1997. Ethylene and abcission. Physiol. Plantarum 100: 567-576.

Byers RE 1997. Effects of aminoethoxyvinylglycine (AVG) on preharvest fruit drop and maturity of 'Delicious' apples. J. Tree Fruit Prod. 2(1): 53-75.

Chu CL 1998. Internal ethylene concentration of 'McIntosh Northern Spy, 'Emperie' 'Mutsu' and 'Idared' apples during the harvest season. J. Amer. Soc. Hortic. Sci. 113: 226-229.

Curry EA 2006. Changes in ripening physiology of 'Delicious' and 'Fuji' apples treated preharvest with NAA. Acta Hort. 727: 481-488.

Dal Cin V, Danesin M, Botton A, Boschetti A, Dorigoni A and Ramina A 2008. Ethylene and preharvest drop: The effect of AVG and NAA on fruit abscission in apple (Malus domestica Borkh.). Plant Growth Regul. 56: 317-325.

Fleancu M 2007. Correlations among some physiological processes in apple fruit during growing and maturation processes. Int. J. Agri. Biol. 9: 613-616.

Gardner FE, Marta PC and Batjer LP 1939. Spraying with plant growth substances for control of the preharvest drop of apples. J. Am. Soc. Hortic. Sci. 37: 415-428.

Greene DW and Schupp JR 2004. Effects of aminoethoxyvinylglycine (AVG) on preharvest fruit drop, fruit quality, and maturation of 'McIntosh' apples. II. Effect of timing and concentration relationships and spray volume. Hortscience. 39: 1036-1041.

Greene DW 2006. An update on preharvest drop control of apples with aminoethoxyvinylglycine (ReTain). Acta Hort. 727: 311-319.

Kang I, Byun J, Kweon H, Kim M, Kwon S, Park M, Lee DH, Choi C and Choi DG 2007. Effects of aminoethoxyvinylglycine on preharvest drop, fruit colour, and quality of 'Tsugaru' Apples. Hortic. Envir. Biotechnol. 48: 159-164.

Marini RP, Byers RE and Sowers DI 1993. Repeated application of NAA control preharvest drop of 'Delicious' apples. J. Hortic. Sci. 68: 247-253.

McGuire RG 1992. Reporting of objective colour measurements. Hortscience 27: 1254-1255.

Petri JL, Leite GB, Argenta LC and Basso C 2006. Ripening delay and fruit drop control in 'Imperial Gala' and 'Suprema' (Fuji Sport) apples by applying AVG (aminoethoxyvinylglycine). Acta Hort. 727: 519526. 
Schupp JR and Greene DW 2004. Effect of aminoethoxyvinylglycine (AVG) on preharvest drop, fruit quality, and maturation of 'McIntosh' apples. I. Concentration and timing of dilute applications of AVG. Hortscience 39: 1030-1035.

Silverman FP, Petracek PD, Noll MR and Warrior P 2004. Aminoethoxyvinylglicine effects on late-season apple fruit maturation. Plant Growth Regul. 43: 153-161.

Stover ED, Fargione MJ, Watkins CB and Iungerman KA 2003. Harvest management of Marshall 'McIntosh' apples: Effects of AVG, NAA, ethephon, and summer pruning on preharvest drop and fruit quality. Hortscience 38: 1093-1099.

Ward DL 2004. Factors affecting preharvest fruit drop of apple. Ph. D. thesis, Virginia Polytechnic Institute and State University, Blacksburg, Virginia, USA. pp. 132.

Wargo JM, Merwin IA and Watkins CB 2004. Nitrogen fertilization, midsummer trunk girdling, and AVG treatments affect maturity and quality of 'Jonagold' apples. Hortscience 39: 493-500.

Williams MW 1980. Retention of fruit firmness and increase in vegetative growth and fruit set of apples with aminoethoxyvinylglycine. Hortscience 15: 76-77.

Whale SK, Singh Z, Behboudian MH, Janes J and Dhaliwal SS 2008. Fruit quality in 'Cripp's Pink' apple, especially colour, as affected by preharvest sprays of aminoethoxyvinylglicine and ethephon. Sci. Hortic.-Amsterdam 115: 342-351.

Yildiz K, Ozturk B and Ozkan Y 2012. Effects of aminoethoxyvinylglycine (AVG) on preharvest fruit drop, fruit maturity, and quality of 'Red Chief' apple. Sci. Hortic.-Amsterdam 144: 121-124.

Yuan R and Carbaugh DH 2007. Effects of NAA, AVG, and 1-MCP on ethylene biosynthesis, preharvest fruit drop, fruit maturity, and quality of 'Golden Delicious' apples. Hortscience 42: 101-105.

(Manuscript received on 23 December, 2014; revised on 2 March, 2015) 